\title{
Differences in the Economic Situation of Organic and Conventional Winemaking Enterprises
}

\author{
E. Vlašicová, Z. Náglová
}

Faculty of Economics and Management, Czech University of Life Sciences Prague, Czech Republic

\begin{abstract}
Anotace
Stejně jako se v České republice rozrůstá základna ekologických zemědělců, také ekologičtí vinaři a biovíno získávají na významu. Článek se zabývá hodnocením a srovnáním ekonomické situace ekologických a konvenčních vinařských podniků v České republice. Mezi lety 2007 a 2011 byla na účetních datech 75 vinařských podniků provedena ekonomická analýza, tj. byly vypočteny ukazatele finanční analýzy, bankrotní modely, ukazatel efektivnosti a ukazatele používané pro hodnocení výkonnosti podnikủ. Pro porovnání hodnot daných ekonomických ukazatelů mezi konvenčními a ekologickými podniky byl použit t-test. Analýza prokázala lepší ekonomickou situaci ekologických vinařských podniků. Vinařské podniky, at’ už ekologické, či konvenční, by měly být schopny hospodařit a generovat zisk i bez dotací.
\end{abstract}

Článek vznikl v rámci řešení projektu IGA 20141046.

\section{Klíčová slova}

Vinařství, ekonomická analýza, t-test, dotace.

\begin{abstract}
The number of organic farms in the Czech Republic is increasing as well as the number of organic winemaking enterprises. The article deals with an evaluation and comparison of the economic situation of organic and conventional winemaking enterprises in the Czech Republic. An economic analysis of the 75 enterprises accounting data from 2007 to 2011 has been done. The financial analysis indicators, bankruptcy models, efficiency indicator and performance indicators were calculated. In order to compare the values of the respective indicators the t-test was used. The performed analysis confirmed a better economic situation of organic winemaking enterprises. Winemaking businesses - whether organic or conventional - are capable of a good financial management and generate profit even without the aid of any subsidies.
\end{abstract}

This article was created as a part of IGA 20141046 project.

\section{Key words}

Wineries, economic analysis, t-test, subsidies.

\section{Introduction}

Vine growing and wine production in some parts of the Czech Republic, especially in southern Moravia, is not only an important part of traditional and cultural practices, but it also significantly contributes to local and regional economies. The current production potential of the Czech Republic is almost 20 thousand hectares of vineyards, however, 17.5 thousand hectares have been utilised. The base of organic farmers as well as the number of organically cultivating winemaking enterprises has been growing. According to the Public Land Register, more than 1,000 ha of organic vineyards are currently registered, which is ca. 6\% of vineyards in the Czech Republic. In 2011 the area of organically cultivated vineyards was half as low.

Wine production in the Czech Republic between 2000 and 2013 was 560 thousands of hectolitres in average, two thirds of which consisted of white wine and one-third of red wine. The annual wine consumption per capita in the Czech Republic continues to grow, currently ranging around 20 litres. „The Czech Republic belongs to the wine-producing countries that are predominantly dependent on imports 
of this commodity. Approximately one third of the consumed wine volume originates from the home production of the Czech Republic and two thirds are imported." (Tomšík and Sedlo, 2013).

Several authors are involved in research of the winemaking sector in the Czech Republic (and elsewhere). Tomšík and Sedlo (2013) analysed production, consumption, export and import of Czech wine. Chládková et al. (2009) or Pyšný et al. (2007) identified the main indicators affecting the trends in demand for wine. In previous years several surveys were performed dealing with wine production and consumption in the Czech Republic, e.g. Šperková and Duda (2009), Sedlo and Tomšík (2012), Hejmalová et al. (2011), Hincl (2012), Kučerová (2014). Hambálková (2006), Kučerová and Žufan (2008), Tomšík and Prokeš (2011a; 2011b), Šperková and Skýpalová (2012), or Vanka and Hejman (2013) examined the winemaking sector from the point of view of methods used in management or marketing. Šperková and Ulbrich (2013) analysed the impact of historical winemaking factors on the current development of the wine sector in the Czech Republic. Koráb (2012), Unwin (2012), Meloni and Swinen (2012) studied the winemaking and winegrowing policies.

Giraud-Héraud and Pichery (2013) wrote a book, which is a summary of scientific articles written by experts from around the world dealing with the economic aspects of the wine sector. Náglová et al. (2014) dealt with the issue from the point of view of a company's economy. These authors explored the impact of capital structure indicators on the economic result of winemaking enterprises.

Development of organic winemaking induces issues concerning the economic efficiency of organic winemaking enterprises. Apart from Náglová's et al. (2014) study, winemaking enterprises have not been detailed examined with regard to their economic or financial situation. The article aims at evaluating and comparing the economic situation of organic and conventional winemaking enterprises. It is a highly specific issue filling in the gap in the area of economic research of winemaking enterprises. The results of the research may be useful for policy makers as well as for the actual wineries, or for the new entrepreneurs in the wine sector.

Based on previous researches dealing with the differences between conventional and organic farming, such as Brožová (2011), Kroupová and Malý (2010), Delbridge et al. (2013) or Lobley et al. (2009), we assumed different economic results in the economic situation of organic and conventional winemaking enterprises.

\section{Materials and methods}

The financial data was obtained from the Albertina database, according to the Classification of Economic Activities (CZ-NACE), the groups "Wine Production from Wine Grapes" (Section C, Class 11.02) and "Grapes Growing" (Section A, Class 01.21) were selected. The missing accounting data was added from the Public Register and the Collection of Deeds administered by the Ministry of Justice. The accountancy data was combined with information from the Register of Organic Farmers and data from the Subsidies Recipients Register (both registers are administrated by the Czech Ministry of Agriculture). The acreage data of enterprises was gathered from the Subsidies Recipients Register and Public Land Register (also administrated by the Czech Ministry of Agriculture).

The total number of winemaking and winegrowing holdings in the Czech Republic is about 11000 of which $98 \%$ are natural persons, however, $60 \%$ of the Czech vineyards are utilised by legal persons. According to the survey of vineyards performed by Czech Statistical Office in 2009, the total number of legal persons was 231 .

The final sample of the Czech winemaking and winegrowing enterprises (hereinafter jointly referred to as winemaking enterprises) was selected on the basis of the entirety of all data and information necessary for analysis. Therefore we had a balanced dataset because all of the data in each year were observed. All of the selected enterprises were the legal persons. In total, we selected 75 winemaking enterprises (i.e. $32 \%$ of the legal persons in the Czech Republic), which had been receiving subsidies either from the EU, or from the Czech national grants from 2007 to 2011. From these, 65 enterprises were conventional and 10 organic.

We performed an analysis of the economic situation of organic and conventional winemaking enterprises using the financial analysis indicators, economic efficiency indicator and performance indicators. All of the indicators were calculated for each enterprise and for each year (2007-2011), however, for purposes of the article the average values of these indicators per every year were used.

The financial analysis methods used included: profitability ratios (return on assets - ROA, return 
on sales - ROS and return on equity - ROE), leverage ratios (total debt to total assets, equity ratio, time interest earned ratio and interest expenses to EBIT), liquidity ratios (current ratio, quick assets ratio and cash position ratio), activity ratios (creditors payment ratios, average collection period, inventory turnover and assets turnover) and bankruptcy models (Altman's model, IN95, $\mathrm{G}$ index, $\mathrm{Ch}$ index). For more details about this models and their construction see Altman (1968), Neumaierová and Neumaier (2002), Gurčík (2002) and Chrastinová (1998). Efficiency of winemaking enterprises (economic efficiency indicator) was calculated as a ratio of costs to revenues. As the performance indicators were used: total costs, operating costs, production consumption, personal expenses, total revenues, operating revenues, sales, production, profit, EBIT (earnings before interest and taxes), added value and subsidies. The performance indicators were recalculated per hectare of agricultural land.

Statistical testing was used to compare the values of above mentioned indicators. Normality of distribution for each indicator was verified by the Shapiro-Wilk test. Data had the normal distribution. The Levene's test for assessing the equality of variances was used. An independent t-test at $5 \%$ and $10 \%$ statistical significance was used for comparison the individual indicators between the conventional and organic winemaking enterprises.

All the tables show for each indicator: median, minimum value, maximum value, 2011 to 2007 percentage change, arithmetic mean, standard deviation, standard error and $t$ values and $p$-values of the t-test. The number of observation (N) was for each indicator 5 due to the fact that the average values of indicators were used for each year of the time period 2007-2011 ( $\mathrm{N}$ value was in the tables omitted).

SPSS programme was used for the analysis.

\section{Results and discussion}

Table 1 captures the results of selected indicators of the financial analysis. Profitability ratios were decreasing in time for both organic and conventional winemaking enterprises. However, the drop was more visible for conventional enterprises. Statistically significant difference on $10 \%$ significance level was confirmed in ROS of organic and conventional enterprises. Higher ROS was achieved by organic farms thanks to higher profit, which is a proof of their more favourable economic situation.

Differences on $10 \%$ significance level are visible for total debt to total assets ratio. This leverage ratio is decreasing in time in the case of organic winemakers. It is also somewhat lower than the leverage ratio of conventional enterprises. The leverage ratio of non-organic enterprises is higher and growing in time. However, in both cases total debt to total assets ratio ranges within the recommended values - up to $60 \%$ (Knápková et al., 2013). Statistically significant differences on $5 \%$ significance level were confirmed for time interest earned ratio and interest expenses to EBIT ratio. Organic winemakers are able to better cover interest expenses by their profit (in average profit exceeds these interests 28.44 times). Organic winemakers can be considered as financially stable. Conventional enterprises are also able to cover the interests. The minimum value of time interest earned ratio is 5 (according to Knápková et al., 2013), it means that profit should exceed interest expenses 5 times. In average, interest expenses draw $4 \%$ from the profit of organic enterprises and $14 \%$ from the profit of conventional enterprises. The ideal value of interest expenses to EBIT is up to $10 \%$ (Synek et al., 2011).

In the area of liquidity both categories of enterprises show similar results. However, slightly better values are again achieved by organic enterprises and the indicator values are growing in time. Current ratio and quick asset ratio is deteriorating in the case of conventional enterprises. Both groups of enterprises have normal average values of current ratio (the recommended values of this indicator should be between 1.5 and 2.5). On the other hand,from the quick assets ratio point of view, organic and conventional winemaking companies are slightly below the suggested limit, which should be between 1 and 1.5 (organic enterprises have 0.93 and conventional businesses have 0.91 ). Based on the cash position ratio results, both groups of winemakers presumably have a problem with paying their liabilities, since the recommended values may range from 0.2 to 0.5 , but the organic companies' average value of this indicator is 0.14 and in the case of conventional enterprises it is 0.1 . The recommended values of liquidity ratios were obtained from Knápková et al. (2013).

Organic winemakers are able to pay their debts earlier (in 152 days in average) than conventional winemakers (in 160 days). The values of this indicator statistically significantly differ between the analysed groups of enterprises on $10 \%$ 
significance level. The sales achieved by organic enterprises contribute to better values of this indicator. Better solvency is also evidenced by the liquidity ratio values that are also higher in case of organic winemakers.

Organic winemakers collect their receivables in 119 days in average (conventional enterprises in 125 days). Statistically significant differences were proved for the assets turnover ratio on 5\% significance level. Higher assets turnover ratios are reported by businesses of organic winemakers due to higher value of assets that reflect better equipment or higher investment activity of these enterprises.

Although the results of the t-test showed the significant differences between the bankruptcy models indicator's values, both groups of enterprises had the same results (see the note under table 2). Altman's model and Index IN95 assessed these enterprises as thriving. Ch index and $G$ index classified organic and conventional winemaking enterprises in the grey zone. The grey zone means that the situation, in which enterprises are, cannot be clearly defined. More information and results of particular models are shown in Table 2.

Based on the economic efficiency indicator (see Table 3), both examined groups of winemaking enterprises - organic and conventional - are evaluated as efficient, since their revenues

\begin{tabular}{|c|c|c|c|c|c|c|c|c|c|c|}
\hline \multirow{2}{*}{ Indicator } & \multirow{2}{*}{ Group } & \multirow{2}{*}{ Median } & \multirow{2}{*}{$\begin{array}{l}\text { Min. } \\
\text { value }\end{array}$} & \multirow{2}{*}{$\begin{array}{l}\text { Max. } \\
\text { value }\end{array}$} & \multirow{2}{*}{$\begin{array}{l}11 / 07 \% \\
\text { change }\end{array}$} & \multirow{2}{*}{$\begin{array}{c}\text { Ar. } \\
\text { mean }\end{array}$} & \multirow{2}{*}{$\begin{array}{l}\text { Std. } \\
\text { dev. }\end{array}$} & \multirow{2}{*}{$\begin{array}{l}\text { Std. } \\
\text { error }\end{array}$} & \multicolumn{2}{|c|}{ t-test } \\
\hline & & & & & & & & & t & p-value \\
\hline \multicolumn{11}{|c|}{ Profitability ratios } \\
\hline \multirow{2}{*}{ ROA (\%) } & Org. & 4.32 & 3.42 & 8.88 & -19.95 & 5.82 & 2.52 & 1.13 & \multirow{2}{*}{1.862} & \multirow{2}{*}{.134} \\
\hline & Conv. & 3.74 & 3.22 & 4.11 & -21.65 & 3.70 & 0.33 & 0.15 & & \\
\hline \multirow{2}{*}{ ROS (\%) } & Org. & 6.28 & 5.59 & 12.27 & -11.08 & 8.29 & 3.20 & 1.43 & \multirow{2}{*}{2.407} & \multirow{2}{*}{.072} \\
\hline & Conv. & 4.83 & 4.42 & 5.36 & -17.44 & 4.83 & 0.35 & 0.16 & & \\
\hline \multirow{2}{*}{ ROE (\%) } & Org. & 9.04 & 7.18 & 16.23 & -4.32 & 11.29 & 4.17 & 1.87 & \multirow{2}{*}{1.903} & \multirow{2}{*}{.129} \\
\hline & Conv. & 7.73 & 7.28 & 8.21 & -6.74 & 7.72 & 0.33 & 0.15 & & \\
\hline \multicolumn{11}{|c|}{ Leverage ratios } \\
\hline \multirow{2}{*}{ Total debt to total assets (\%) } & Org. & 40.90 & 19.27 & 51.45 & -62.55 & 39.70 & 12.59 & 5.63 & \multirow{2}{*}{-2.056} & \multirow{2}{*}{.074} \\
\hline & Conv. & 50.09 & 49.58 & 57.51 & 15.99 & 51.66 & 3.32 & 1.48 & & \\
\hline \multirow{2}{*}{ Equity ratio (\%) } & Org. & 50.66 & 39.59 & 60.12 & -16.33 & 51.11 & 8.28 & 3.70 & \multirow{2}{*}{0.797} & \multirow{2}{*}{.448} \\
\hline & Conv. & 49.55 & 42.04 & 50.04 & -15.99 & 47.93 & 3.35 & 1.50 & & \\
\hline T.. & Org. & 24.81 & 15.24 & 50.47 & 42.34 & 28.44 & 13.42 & 6.00 & 2 & $00 \mathrm{P}$ \\
\hline Time interest earned ratio & Conv. & 7.37 & 6.01 & 9.40 & -20.57 & 7.41 & 1.26 & 0.56 & 3.489 & .024 \\
\hline L & Org. & 4.03 & 1.98 & 6.56 & -29.75 & 4.10 & 1.69 & 0.76 & 7020 & 0 \\
\hline Interest exp. to ЕВ11 (\%) & Conv. & 13.57 & 10.63 & 16.65 & 25.89 & 13.79 & 2.19 & 0.98 & -1.830 & .000 \\
\hline & & & & quidity $r$ & ios & & & & & \\
\hline C. & Org. & 2.09 & 1.79 & 2.44 & 36.23 & 2.05 & 0.27 & 0.12 & 10000 & POP \\
\hline Current ratio & Conv. & 1.83 & 1.64 & 1.91 & -14.40 & 1.80 & 0.10 & 0.05 & 1.932 & .089 \\
\hline . I t a t. & Org. & 0.93 & 0.80 & 1.05 & 16.94 & 0.93 & 0.11 & 0.05 & 0260 & 720 \\
\hline Quick assets ratio & Conv. & 0.93 & 0.71 & 1.01 & -27.10 & 0.91 & 0.12 & 0.05 & 0.368 & .123 \\
\hline 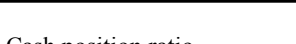 & Org. & 0.13 & 0.07 & 0.21 & 173.41 & 0.14 & 0.06 & 0.03 & 1020 & 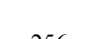 \\
\hline Casn position ratio & Conv. & 0.10 & 0.07 & 0.15 & 26.41 & 0.10 & 0.03 & 0.01 & 1.224 & .256 \\
\hline & & & & ctivity ra & & & & & & \\
\hline Croditore noument priod & Org. & 143.91 & 132.86 & 176.84 & -18.62 & 151.69 & 18.79 & 8.40 & 1 000 & \\
\hline Creditors payment period & Conv. & 163.33 & 152.31 & 167.07 & 6.49 & 160.78 & 6.50 & 2.90 & -1.023 & .354 \\
\hline 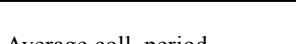 & Org. & 124.64 & 103.59 & 127.78 & -18.93 & 118.71 & 11.09 & 4.96 & 0610 & 550 \\
\hline Average coll. period & Conv. & 129.35 & 96.84 & 136.91 & -27.99 & 124.06 & 16.16 & 7.23 & -0.610 & .559 \\
\hline 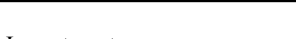 & Org. & 156.11 & 139.45 & 216.73 & 23.44 & 168.18 & 30.05 & 13.44 & 1.700 & \\
\hline 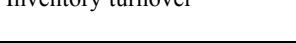 & Conv. & 146.10 & 126.06 & 153.28 & 5.26 & 143.64 & 10.30 & 4.61 & 1.728 & .122 \\
\hline A coote thenom & Org. & 512.63 & 500.30 & 595.78 & 11.08 & 529.90 & 39.38 & 17.61 & 2842 & 002 \\
\hline Assets turnover & Conv. & 470.99 & 467.22 & 501.50 & 5.38 & 476.60 & 14.36 & 6.42 & & \\
\hline
\end{tabular}

Source: own processing

Table 1: Financial analysis of organic and conventional winemaking enterprises. 


\begin{tabular}{|c|c|c|c|c|c|c|c|c|c|c|}
\hline \multirow{2}{*}{ Indicator } & \multirow{2}{*}{ Group } & \multirow{2}{*}{ Median } & \multirow{2}{*}{$\begin{array}{l}\text { Min. } \\
\text { value }\end{array}$} & \multirow{2}{*}{$\begin{array}{l}\text { Max. } \\
\text { value }\end{array}$} & \multirow{2}{*}{$\begin{array}{l}11 / 07 \% \\
\text { change }\end{array}$} & \multirow{2}{*}{$\begin{array}{c}\text { Ar. } \\
\text { mean }\end{array}$} & \multirow{2}{*}{$\begin{array}{l}\text { Std. } \\
\text { dev. }\end{array}$} & \multirow{2}{*}{$\begin{array}{l}\text { Std. } \\
\text { error }\end{array}$} & \multicolumn{2}{|c|}{ t-test } \\
\hline & & & & & & & & & t & p-value \\
\hline \multirow{2}{*}{ Altman's model } & Org. & 4.34 & 4.03 & 4.61 & 14.23 & 4.29 & 0.25 & 0.11 & \multirow{2}{*}{43.658} & \multirow{2}{*}{.000} \\
\hline & Conv. & -1.04 & -1.25 & -0.95 & 21.07 & -1.07 & 0.11 & 0.05 & & \\
\hline \multirow{2}{*}{ IN95 } & Org. & 3.18 & 3.01 & 3.24 & -5.34 & 3.14 & 0.10 & 0.04 & \multirow{2}{*}{8.952} & \multirow{2}{*}{.000} \\
\hline & Conv. & 0.03 & -1.55 & 0.58 & -368.05 & -0.17 & 0.82 & 0.37 & & \\
\hline \multirow{2}{*}{ Ch index } & Org. & 0.36 & 0.31 & 0.37 & -13.06 & 0.35 & 0.02 & 0.01 & \multirow{2}{*}{3.964} & \multirow{2}{*}{.004} \\
\hline & Conv. & 0.25 & 0.23 & 0.32 & -2.01 & 0.27 & 0.04 & 0.02 & & \\
\hline \multirow{2}{*}{$\mathrm{G}$ index } & Org. & 0.31 & 0.09 & 0.39 & -72.00 & 0.28 & 0.12 & 0.05 & \multirow{2}{*}{6.315} & \multirow{2}{*}{.000} \\
\hline & Conv. & -1.18 & -2.45 & -1.04 & 135.03 & -1.42 & 0.59 & 0.26 & & \\
\hline
\end{tabular}

Note: Rating scale for Altman: $\mathrm{Z}>2.9$ thriving; $1.23<\mathrm{Z}<2.9$ grey zone; $\mathrm{Z}<1.23$ risk of bankruptcy. For IN95: IN95 $>2$ no problems with paying liabilities; $1<\mathrm{IN} 95<2$ grey zone; IN95<1 problems with paying liabilities. For $\mathrm{Ch}$ index: $\mathrm{Ch}>2.5$ thriving; $2.5>\mathrm{Ch}>-5$ grey zone; $\mathrm{Ch}<-5$ risk of bankruptcy. For $\mathrm{G}$ index: $\mathrm{G}>1.8$ thriving; $1.8>\mathrm{G}>-0.6$ grey zone; $\mathrm{G}<-0.6$ risk of bankruptcy.

Source: own processing

Table 2: Bankruptcy models of organic and conventional winemaking enterprises.

\begin{tabular}{|c|c|c|c|c|c|c|c|c|c|c|}
\hline \multirow{2}{*}{ Indicator } & \multirow{2}{*}{ Group } & \multirow{2}{*}{ Median } & \multirow{2}{*}{$\begin{array}{l}\text { Min. } \\
\text { value }\end{array}$} & \multirow{2}{*}{$\begin{array}{l}\text { Max. } \\
\text { value }\end{array}$} & \multirow{2}{*}{$\begin{array}{c}11 / 07 \% \\
\text { change }\end{array}$} & \multirow{2}{*}{$\begin{array}{c}\text { Ar. } \\
\text { mean }\end{array}$} & \multirow{2}{*}{$\begin{array}{l}\text { Std. } \\
\text { dev. }\end{array}$} & \multirow{2}{*}{$\begin{array}{c}\text { Std. } \\
\text { error }\end{array}$} & \multicolumn{2}{|c|}{ t-test } \\
\hline & & & & & & & & & $t$ & p-value \\
\hline \multirow{2}{*}{ Economic efficiency (\%) } & Org. & 109.47 & 106.21 & 116.57 & -2.97 & 111.31 & 4.52 & 2.02 & \multirow{2}{*}{2.296} & \multirow{2}{*}{.082} \\
\hline & Conv. & 106.67 & 106.14 & 107.18 & 0.48 & 106.65 & 0.37 & 0.17 & & \\
\hline
\end{tabular}

Source: own processing

Table 3: Economic efficiency of organic and conventional winemaking enterprises.

in all examined years exceeded their costs. Organic farms were on average in the given time series by $4 \%$ more efficient than conventional businesses. The development of the indicator for conventional farms can be described as constant, while the economic efficiency of organic farms varied between 2007 and 2011. The statistically significant difference between organic and conventional enterprises in the economic efficiency indicator can be seen on $10 \%$ significance level.

The results of performance indicators are shown in Table 4. On 5\% level of significance we can state a significant difference between organic and conventional winemakers in the total revenues, operating revenues and production parameter. On $10 \%$ level of significance we observed significant differences in operating costs, production consumption, sales, profit, EBIT and added value.

The average total costs of an organic winemaking enterprise per hectare of vineyard or hectare of agricultural land are 1,227 thousand CZK and average total costs of a conventional enterprise are 1,139 thousand CZK per hectare. The higher total costs of organic enterprise are caused by the higher production consumption (especially by consumption of material and energy). However, the difference is not significant. The share of production consumption in total costs of both groups of winemaking enterprises is $75 \%$, the share of personal expenses is $10 \%$ and the share of consumption of material and energy is $50 \%$. The average costs of viticulture (costs of running a vineyard) are around 100 thousand CZK annually (Sedlo, 2009) and in the case of organic winemakers it is approximately $10 \%$ higher. Moreover, the yield of hectare of organic vineyard is lower than the conventional one. For instance, according to Ministry of Agriculture, the national average vineyard hectare yield in 2011 was 5.7 tonnes per hectare, whereas the organic vineyard produced approximately 3.4 tonnes of grapes per hectare. Nevertheless, the costs of growing grapes do not constitute a major share in the total cost. According to the Ministry of Agriculture (2012) only about $20 \%$ of Czech wine producers are involved in winegrowing and in-house processing of the harvested grapes without purchasing additional grapes from other winegrowing businesses (the survey was performed on a sample of 100 enterprises). Some companies are more focused on production of grapes for further sale while other specialize in winemaking and purchase grapes. Other activities generating costs and later also revenues are related to processing of vine and grapes, production of wine, promotion and distribution, and activities related to gastronomy and tourism.

The average total revenues of winemaking enterprises are 1,364 thousand $\mathrm{CZK} / \mathrm{ha}$ 


\begin{tabular}{|c|c|c|c|c|c|c|c|c|c|c|}
\hline \multirow{2}{*}{ Indicator } & \multirow{2}{*}{ Group } & \multirow{2}{*}{ Median } & \multirow{2}{*}{$\begin{array}{l}\text { Min. } \\
\text { value }\end{array}$} & \multirow{2}{*}{$\begin{array}{l}\text { Max. } \\
\text { value }\end{array}$} & \multirow{2}{*}{$\begin{array}{c}\text { 11/07 \% } \\
\text { change }\end{array}$} & \multirow{2}{*}{$\begin{array}{c}\text { Ar. } \\
\text { mean }\end{array}$} & \multirow{2}{*}{$\begin{array}{l}\text { Std. } \\
\text { dev. }\end{array}$} & \multirow{2}{*}{$\begin{array}{l}\text { Std. } \\
\text { error }\end{array}$} & \multicolumn{2}{|c|}{ t-test } \\
\hline & & & & & & & & & t & p-value \\
\hline \multirow{2}{*}{ Total costs } & Org. & 1209.81 & 1099.50 & 1364.60 & 24.11 & 1227.17 & 98.97 & 44.26 & \multirow{2}{*}{1.790} & \multirow{2}{*}{0.111} \\
\hline & Conv. & 1118.97 & 1090.72 & 1190.48 & -8.26 & 1139.45 & 46.98 & 21.01 & & \\
\hline \multirow{2}{*}{ Operating costs } & Org. & 1196.71 & 1084.53 & 1353.91 & 24.84 & 1215.87 & 100.54 & 44.96 & \multirow{2}{*}{2.083} & \multirow{2}{*}{0.071} \\
\hline & Conv. & 1093.85 & 1064.97 & 1164.54 & -7.90 & 1113.58 & 44.20 & 19.76 & & \\
\hline \multirow{2}{*}{ Production consumption } & Org. & 902.61 & 796.86 & 1032.72 & 29.60 & 908.20 & 83.92 & 37.53 & \multirow{2}{*}{2.051} & \multirow{2}{*}{0.074} \\
\hline & Conv. & 811.60 & 801.99 & 875.15 & 8.48 & 826.35 & 30.30 & 13.55 & & \\
\hline \multirow{2}{*}{ Personal expenses } & Org. & 135.63 & 109.94 & 138.80 & 26.26 & 128.49 & 12.84 & 5.74 & \multirow{2}{*}{-0.699} & \multirow{2}{*}{0.504} \\
\hline & Conv. & 133.05 & 117.99 & 150.57 & 27.61 & 133.96 & 11.92 & 5.33 & & \\
\hline \multirow{2}{*}{ Total revenues } & Org. & 1385.09 & 1203.57 & 1449.37 & 20.42 & 1364.23 & 93.64 & 41.88 & \multirow{2}{*}{3.180} & \multirow{2}{*}{0.013} \\
\hline & Conv. & 1192.12 & 1169.04 & 1268.29 & -7.83 & 1215.11 & 47.16 & 21.09 & & \\
\hline \multirow{2}{*}{ Operating revenues } & Org. & 1377.62 & 1187.82 & 1442.39 & 21.43 & 1350.48 & 95.96 & 42.92 & \multirow{2}{*}{3.168} & \multirow{2}{*}{0.013} \\
\hline & Conv. & 1181.87 & 1160.66 & 1247.95 & -6.92 & 1201.93 & 42.24 & 18.89 & & \\
\hline \multirow{2}{*}{ Sales } & Org. & 1256.76 & 1055.13 & 1362.19 & 14.72 & 1244.80 & 122.52 & 54.79 & \multirow{2}{*}{1.873} & \multirow{2}{*}{0.098} \\
\hline & Conv. & 1148.45 & 1110.14 & 1168.54 & 4.11 & 1140.02 & 25.21 & 11.28 & & \\
\hline D d o t. & Org. & 1213.78 & 1036.59 & 1268.11 & 22.34 & 1189.69 & 88.98 & 39.79 & 2211 & 0011 \\
\hline Production & Conv. & 1051.88 & 1020.84 & 1096.55 & -3.43 & 1050.67 & 29.98 & 13.41 & 3.311 & 0.011 \\
\hline & Org. & 82.64 & 66.29 & 164.30 & 2.01 & 104.49 & 45.41 & 20.31 & & \\
\hline Profit & Conv. & 54.85 & 51.13 & 59.49 & -14.05 & 54.98 & 3.02 & 1.35 & 2.432 & 0.071 \\
\hline FPIT & Org. & 112.61 & 88.48 & 186.59 & -14.34 & 134.61 & 46.22 & 20.67 & 2205 & 0080 \\
\hline EDI1 & Conv. & 88.02 & 83.41 & 95.69 & 5.52 & 88.35 & 5.08 & 2.27 & 2.225 & 0.089 \\
\hline Added ulu & Org. & 337.99 & 267.62 & 346.15 & 3.85 & 313.63 & 37.61 & 16.82 & 2473 & 0052 \\
\hline Added value & Conv. & 272.79 & 243.64 & 285.58 & 2.15 & 268.18 & 16.57 & 7.41 & 2.473 & 0.052 \\
\hline C & Org. & 49.45 & 21.98 & 78.77 & -72.10 & 48.78 & 23.62 & 10.56 & 750 & 0.117 \\
\hline Subsidies & Conv. & 28.65 & 17.46 & 38.77 & -39.06 & 29.00 & 8.60 & 3.85 & 1.759 & 0.117 \\
\hline
\end{tabular}

Note: All indicators were recalculated per hectare of agricultural land.

Source: own processing

Table 4: Performance indicators of organic and conventional winemaking enterprises.

for organic enterprises and 1,215 thousand $\mathrm{CZK} / \mathrm{ha}$ for conventional enterprises. The share of production in these revenues is $87 \%$ for organic and $86 \%$ for conventional enterprises. The difference between the evaluated groups of companies is obvious in the profit indicator (but not statistically significant). Organic winemaking enterprises achieve almost twice as high average annual profit per hectare (104 thousand $\mathrm{CZK} / \mathrm{ha}$ ) as conventional enterprises (55 thousand $\mathrm{CZK} / \mathrm{ha}$ ). The average annual added value of organic enterprises is 50 thousand CZK per hectare higher than that of conventional enterprises (average added value of organic winemaking enterprises is 314 thousand $\mathrm{CZK} /$ ha, whereas by conventional it is 264 thousand $\mathrm{CZK} / \mathrm{ha}$ ). The higher profit of organic winemaking enterprises is mainly due to the better quality of wine, which is on the market for higher prices sold. Furthermore, organic enterprises more tend to diversification their activities that can insure them, for instance, against a loss caused by natural and climatic conditions.
The differences are noticeable for the subsidies parameter too, however, regarding to the t-test, the differences are not statistically significant. Organic winemaking enterprises have average subsidies per hectare of almost 49 thousand CZK, while conventional winemaking enterprises annually received by 20 thousand CZK less of subsidies in average. In addition to subsidies, which are intended for winemakers, organic enterprises may also apply for a higher amount of subsidies than conventional businesses, in particular the support for organic farming, which is part of the Agri-environmental measure of the Rural Development Programme. Subsidies allocated to support organic agriculture are intended to compensate for the higher positive externalities induced by organic farming in comparison with conventional agriculture, and to pay for internalization of negative externalities. Due to the existence of positive externalities a lower quantity of goods is produced than what is required for social welfare (Soukupová et al., 2004; 
Kroupová and Malý, 2010).

Both groups of companies are able to cover their production consumption and personal expenses by the generated output. We can state that winemaking enterprises are able to financially manage and generate profit even without the aid of subsidies, because after removing agricultural subsidies from economy of these enterprises, a certain reserve in profit still remains for both organic and conventional winemaking enterprises, however, their profit was decreased ca. by $50 \%$. Kroupová and Malý (2010) observed during modelling of organic farming with and without subsidies, that subsidies directed to organic enterprises have a negative impact on the profit of these companies. Organic enterprises receiving subsidies may eventually achieve by $15 \%$ lower profit than had they not received any subsidies. Subsidies provided to organic enterprises may also increase the level of costs and reduce technical efficiency. However, we have not done any deeper analysis related to subsidies impact on the economic situation of winemaking enterprises. Therefore we cannot claim that subsidies can be removed in the case of winemaking enterprises. For this reason, a questionnaire survey or interviews with winemaking enterprises should be done. The survey could bring more data as well as information about the subsidies usage, such as for what purposes they were used and whether they were used effectively, or whether subsidies brought winemakers what they expected.

When comparing winemaking and winegrowing enterprises with agricultural businesses, we can say that winemaking enterprises are economically more efficient than businesses focusing on the production and processing of agricultural commodities (except wine and wine grapes), (authors' own research or can be compared with data from FADN, or e.g. with the results Lososová and Zdeněk, 2014). It would thus seem advisable for agricultural business to try to diversify their agricultural commodities and include production of grapes. However, a detailed analysis of the economy of grape production indicated that winegrowing is unprofitable, the purchase prices of grapes are not high enough and the return per hectare of grapes fluctuates year-on-year (authors' own research or e.g. Sedlo, 2009; Ministry of Agriculture, 2012). Due to this reason winemaking and winegrowing enterprises diversify their activities and often add some services to their production, e.g. accommodation, hospitality and retail (authors' own research).

\section{Conclusion}

Certain differences in the economic situation of organic winemaking enterprises and conventional winemaking enterprises were observed. Organic winemaking enterprises have a slightly better economic situation. Their profitability and solvency are higher and indebtedness is lower. Organic winemaking enterprises have a higher economic efficiency indicator as well as all of the performance indicators. Their profit and subsidies per hectare are almost twice as high. Both groups of winemaking enterprises were assessed as thriving according to the Altman's model and Index IN95, however, $\mathrm{Ch}$ index and $\mathrm{G}$ index classified them in the grey zone.

Winemaking business - whether organic or conventional - are capable of good financial management and generate profit even without the aid of any subsidies. Nevertheless, a deeper analysis related to subsidies impact on the economic situation of winemaking enterprises may be done. We suggest performing a deep questionnaire survey or interviews with winemaking enterprises about their economic situation. The survey could bring more data as well as information about the subsidies, input or output usage.

We recommend adding into the Czech Winemakers Association survey more enterprises (annually they collect data from 100 winemakers) as well as extending the surveyed information about economic data. It could help better understand the economic aspects in the winemaking sector and help in decision-making within the wine policy.

\section{Acknowledgement}

This article was created with the support of the Internal grant agency of the Faculty of Economics and Management of the Czech University of Life Sciences Prague. Grant title: Economic efficiency of the winemaking and winegrowing sector in the Czech Republic - opportunities for development of the sector. Registration number 20141046. 
Corresponding author:

Ing. Eliška Vlašicová, Ing. Zdeňka Náglová

Department of Economics, Faculty of Economics and Management

Czech University of Life Sciences in Prague, Kamýcká 129, Prague 6-Suchdol, Czech Republic

E-mail:vlasicova@pef.czu.cz,naglova@pef.czu.cz

Ing. Zdeňka Náglová

Department of Economics, Faculty of Economics and Management

Czech University of Life Sciences in Prague, Kamýcká 129, Prague 6-Suchdol, Czech Republic

E-mail:naglova@pef.czu.cz

\section{References}

[1] Altman E. I. Financial Ratios, Discriminant Analysis, and the Prediction of Corporate Bankruptcy. Journal of Finance, 1968, Vol. 23, No. 4, p. 589-609. ISSN 1540-6261.

[2] Brožová I. The economic performance analysis of organic farms in the Czech Republic. Agriculturae et Silviculturae mendelianae Brunensis, 2011, Vol. 56, No. 2, p. 297-308. ISSN 1211-8516.

[3] Delbridge, T. A., Fernholz, C., King, R., Lazarus, W. A whole-farm profitability analysis of organic and conventional cropping systém.. Agricultural Systems, 2013, Vol. 122, p. 1-10. ISSN 0308-521X.

[4] Chládková H., Tomšík P., Gurská S. The development of main factors of the wine demand. Agricultural Economics - Czech, 2009, Vol. 55, No. 7, p. 321-326. ISSN 1805-9295.

[5] Chrastinová Z. Metódy hodnotenia ekonomickej bonity a predikce finančnej situácie pol'nohospodárských podnikov. VÚEPP, Bratislava, 1998. ISBN 80-7079-641-3.

[6] Giraud-Héraud E., Pichery M. C. Wine Economics: Quantitative Studies and Empirical Applications. Palgrave Macmillan, London, 2013. ISBN 978-1-137-28951-3.

[7] Gurčík L. G-index - metóda predikcie finančného stavu polnohospodárských podnikov. Agricultural Economics - Czech, 2002, Vol. 48, No. 8, p. 373-378. ISSN 1805-9295.

[8] Hambalková M. The factors of competitiveness and the quantification of their impact on the export efficiency of grape and wine in the Slovak Republic. Agricultural Economics - Czech, 2006, Vol. 52, No. 8, p. 389-394. ISSN 1805-9295.

[9] Hejmalová H., Šperková R., Duda J. The Role of the Wine-Production Industry in South Moravia. Agrarian Perpsectives, International Scientific Conference, Prague, 2011, p. 209-216. ISBN 978-80-213-2419-0.

[10] Hicl Z. Evaluation of viniculture in the Czech Republic from the perspective of industry and prediction of development until 2020 according to selected variables. Acta Universitatis Agriculturae et Silviculturae Mendelianae Brunensis, 2012, Vol. 60, No. 7, p. 89-100. ISSN 1211-8516.

[11] Knápková, A., Pavelková D., Šteker, K. Finanční analýza: komplexní průvodce s př́íklady. 2013, Grada, Prague. ISBN 978-80-247-4456-8.

[12] Koráb P. European Wine Policy and Perceptions of Moravian Winemarkets a Pilot Study in the Czech Republic. Acta Universitatis Agriculturae et Silviculturae Mendelianae Brunensis, 2012, Vol. 60, No. 4, p. 207-214. ISSN 1211-8516.

[13] Kroupová Z., Malý M. Analysis of Agriculture Subsidy Policy Tools - Aplication of Production Function. Politická ekonomie, 2010, No. 6, p. 774-794. ISSN 0032-3233.

[14] Kučerová R. Factors of the attractiveness of Slovak wine market and their influence on the Czech wine export to Slovakia. Agricultural Economics - Czech, 2014, Vol. 60, No. 9, p. 430-439. ISSN 1805-9295.

[15] Kučerová R., Žufan P. Market position of selected competitors of the Czech wine market. Agricultural Economics - Czech, 2008, Vol. 54, No. 7, p. 343-346. ISSN 1805-9295. 
[16] Lobley M., Burtler A., Reed M. The contribution of organic farming to rural development: An exploration of the soci-economic linkages of organic and non-organic farms in England. Land Use Policy, 2009, Vol. 26, p. 723-735. ISSN 0264-8377.

[17] Lososová J., Zdeněk R. Key Factors Affecting the Profitability of Farms in the Czech Republic. Agris on-Line Papers in Economics and Informatics, 2014, Vol. 6, No. 1, p. 21-36. ISSN 1804-1930.

[18] Meloni G., Swinnen J. The Political Economy of European Wine Regulations. LICOS Discussion Paper Series. 2012, Discussion Paper 320/2012. Leuven.

[19] Ministry of Agriculture. Situation and Outlook Report: vine and wine. Ministry of Agriculture Czech Republic, 2012. ISSN 1211-7692.

[20] Náglová Z., Vlašicová E., Gürtler M., Gryčová M. The Impact of Indicators of Capital Structure on Profit of Viticulture and Viniculture Enterprises. European Financial Systems 2014 - Proceedings of the $11^{\text {th }}$ International Scientific Conference, Masaryk University, Lednice, 2014, p. 409-416. ISBN 978-80-210-7153-7.

[21] Neumaierová, I., Neumaier, I. Výkonnost a tržní hodnota firmy. 2002, Grada, Prague. ISBN 80-247-0125-1.

[22] Pyšný T., Pošvář Z., Gurská S. Analysis of selected demand factors of wine market of the Czech Republic. Agricultural Economics - Czech, 2007, Vol. 53, No. 7, p. 304-311. ISSN 1805-9295.

[23] Sedlo J., Tomšík P. Strategic development of varietal vineyards in the Czech Republic. Acta Universitatis Agriculturae et Silviculturae Mendelianae Brunensis, 2012, Vol. 60, No. 2, p. 325-334. ISSN 1211-8516.

[24] Sedlo J. Ekonomika vinohradnictví ČR (2009); (Economy of viniculture in the Czech Republic). 2009, Svaz vinařŭ ČR. www.svcr.cz

[25] Soukupová J. et. al. Mikroekonomie. 2004, Management Press, Prague. ISBN 80-7261-061-9.

[26] Synek M., Kislingerová E. Podniková ekonomika. 2010, Beck, Prague. ISBN 978-80-7400-336-3.

[27] Šperková R., Duda J. Preliminary situation analysis of wine production industry in the Czech Republic since 1989. Acta Universitatis agriculturae et silviculturae Mendelianae Brunensis, 2009, Vol. 57, No. 6, p. 287-296. ISSN 1211-8516.

[28] Šperková R., Skýpalová, R. Strategic options for newly entering companies into the wine sector in the Czech Republic. Acta Universitatis Agriculturae et Silvicul $\neg$ turae Mendelianae Brunensis, 2012 , Vol. 60, No. 7, p. 387-398. ISSN 1211-8516.

[29] Šperková R., Ulbrich T. History and Present of the Viticulture branch in the Czech Republic. The International Scientific Conference INPROFORUM 2013, 2013, p. 323-328. ISBN 978-80-7394-440-7.

[30] Tomšík P., Prokeš M. Formation of Regional Associations of Wine Producers in the Czech Republic. Agrarian Perpsectives, International Scientific Conference, Prague, 2011a, p. 263-270. ISBN 978-80-213-2419-0.

[31] Tomšík P., Prokeš M. New Strategic Alliances of Wine Producers in the Czech Republic. Agricultural Economics - Czech, 2011b, Vol. 57, No. 12, p. 573-579. ISSN 1805-9295.

[32] Tomšík P., Sedlo J. Management of wine production with regard to its implementation into the wine markets of the Czech Republic. Agricultural Economics - Czech, 2013, Vol. 59, No. 5, p. 202-210. ISSN 1805-9295.

[33] Unwin T. Wine and the Vine: An Historical Geography of Viticulture and the Wine Trade. 2012, Taylor \& Francis, London. ISBN 0-415-03120-6.

[34] Vanka G. M., Hejman W. J. M. The Kosovar wine cluster: A booster for regional development? Agricultural Economics - Czech, 2013, Vol. 59, No. 4, p. 167-182. ISSN 1805-9295. 